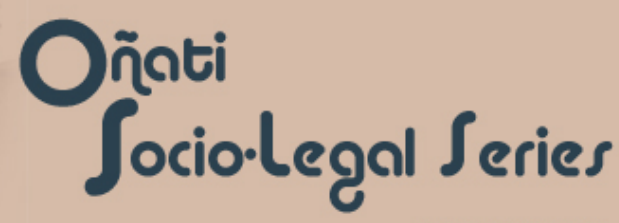

ISSN: 2079-5971

Oñati Socio-legal Series, v. 9, n. 4 (2019) - La institucionalización de la mediación: potencialidades y riesgos

ISSN: 2079-5971

\title{
Family Mediation in the Basque Country: Strengths and Risks
}

CRISTINA MERINO* ROBERTO MORENO*

Merino, C., y Moreno, R., 2019. Family Mediation in the Basque Country: Strengths and Risks. Received 04 May 2018, Accepted 18 January 2019. Oñati Socio-legal Series [online], 9(4), 541-547. Available from: https://doi.org/10.35295/osls.iisl/0000-0000-0000-1094

\begin{abstract}
This paper will show a picture of the family mediation in Basque Country, both at courts and out of courts. On one hand, family mediation started with a pilot project in Bilbao in 1996 and two decades later it is offered in every province of Basque Country (Ministry of Social Affairs). After 20 years working in this field we have observed some strengths and risks we would like to share and to think about them. On the other hand, regarding mediation at courts, since 2007 the Basque Government (Ministry of Labour and J ustice) decided to improve Restorative J ustice $(R J)$ in the Basque Country by Victim Offender Mediation Services at criminal courts of the main cities. Since 2011, we realized that many other proceedings are very suitable to be solved by $\mathrm{RJ}$ in some civil matters and we started providing mediation in family matters of divorces and separations with children involved.
\end{abstract}

\section{Key words}

Mediation; family mediation; strengths; risks; assessment; VOM services; training; Restorative Justice

\section{Resumen}

El artículo ofrece un retrato de la mediación familiar en el País Vasco. La mediación familiar comenzó con un proyecto piloto en Bilbao en 1996 y, dos décadas después, se ofrece en todas las provincias del País Vasco (Departamento de Políticas Sociales). Después de 20 años, hemos observado algunos puntos fuertes y algunos riesgos de los que queremos informar e invitar a la reflexión conjunta. Por otro lado, en lo tocante a la mediación en los juzgados, en 2007 el Gobierno Vasco (Departamento

\footnotetext{
* Cristina Merino (PhD, Psychology) is a mediator in the out of court Family Mediation Service in the Basque Government, and a Team coordinator. Contact details: c/Santutxu, no 69, planta baja; Bilbao 48006. Email: c.merino.ortiz@gmail.com

${ }^{*}$ Roberto Moreno is the Head of the Justice Service for Adults of the Ministry of Labour and Justice of the Basque Government. He coordinates the Restorative Justice Service at criminal courts and family matters of the Basque Country, also the Victim Support Service and the Probation Service. He represents technically Justice Ministry of the Basque Government for coordination among institutions in domestic violence matters and is responsible for granting rehabilitation projects for prisoners. In the past he has 10 years' experience defending prisoners' rights in prison, legal advising, visiting at prison and struggling at courts for their rights in different civil movements and NGOs. He is a member of the Board of the European Forum for Restorative Justice. Email: ro-moreno@euskadi.eus
}

\section{(cc) EY-NC-ND}

Oñati International Institute for the Sociology of Law Antigua Universidad s/n - Apdo.28 20560 Oñati - Gipuzkoa - Spain

Tel. (+34) 943783064 
de Trabajo y Justicia) decidió mejorar la Justicia Restaurativa (JT) en el País Vasco, con Servicios de Mediación Víctima-Ofensor en juzgados de lo penal de las principales ciudades. Desde 2011, hemos visto que hay muchos otros procedimientos de asuntos civiles que se pueden resolver mediante la JT, y hemos comenzado a proporcionar mediación en casos de divorcios y separaciones con niños implicados.

\section{Palabras clave}

Mediación; mediación familiar; fortalezas; riesgos; valoración; servicios MVO; capacitación; J usticia Restaurativa 


\section{Table of contents / Índice}

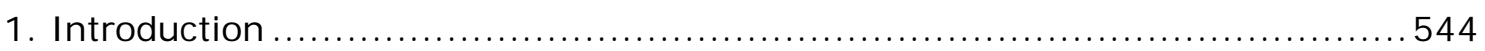

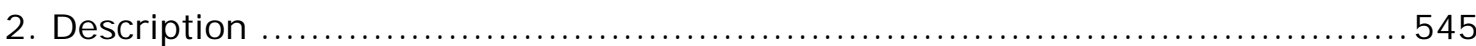

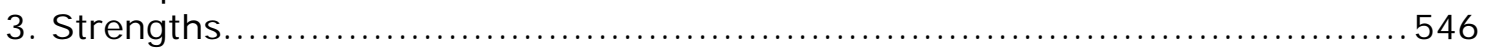

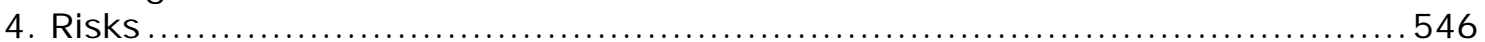

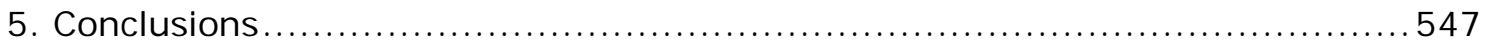

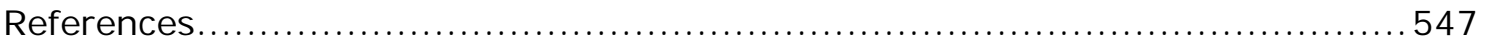




\section{I ntroduction}

This paper will show a picture of the family mediation in the Basque Country.

Online Digital Services (ODR) for family disputes have not arrived to the Basque Country yet. We consider the Alternative Dispute Resolution (ADR) offers a range of processes. The alternative processes in family contexts are mediation, Family Group Conferences, Restorative circles, even individual assessment focused on conflict management. This variety of processes implies that the answer to the family conflict could be more accurate to every family, context and conflict. So flexibility and adaptation are two of the main advantages of this approach.

The mediation is offered to the Basque population in court services as well as out of the court ones.

On the one hand, regarding out of the court family mediation, in our autonomous community, the Basque Government started the first Family Mediation Service, as a pilot project in Bilbao in 1996 and two decades later it's offered in every capital of the three provinces of the Basque Country (Merino 2010). After more than 20 years working in this field, we have observed some strengths and risks we would like to share and to reflect on them.

Regarding mediation in courts, in 2007 the Basque Government (Ministry of J ustice) decided to improve Restorative Justice in the Basque Country by Victim Offender Mediation (VOM) Services in criminal courts of the three main cities and the 4th biggest city, Barakaldo. Since then, the legal frame has been the same: there is not any regulation of the mediation in criminal law. In spite of that, we have continued establishing and reinforcing VOM services as an alternative way of justice (restorative justice) but always inside formal justice in courts and regulated by protocols with formal justice boards (judges, prosecutors and lawyers). As a result of these efforts since 2011 we have acted in all criminal courts of the Basque Country with mediators in all those judicial districts.

After years of experience in criminal cases we realized that many other proceedings in courts had conflicts underneath that are very suitable to be solved by restorative justice in some civil matters. To get this attempt under control, as the amount of referrals could be huge, and no more budgets or personal resources were given to us, we started with family matters of divorces and separations in those cases in which children were involved. It was both quantitative and qualitative criteria. Firstly, in order to protect minors and also because many times these conflictive cases had a direct impact in criminal courts when some of them become criminal offenses as much as not paying children support pension and so on. Moreover, from the Ministry of J ustice of the Basque Government our reference is to work supporting Restorative J ustice (public law, mainly criminal matters), not only mediation as a technique. But the evolution of the paradigm of RJ during last times, implies widening the scope of the RJ to social problems in which it is a conflict below, this is the case the separations and divorces with children where other members of the family (extended family) and the society is fully affected. As we are part of the European Forum for Restorative J ustice we have experienced this evolution directly, and that way nowadays RJ is being used in Europe to tackle with intercultural conflicts or de-radicalization processes or working only with victims when the offenders are unknown (reparation, Victim Support Services, etc.) [Moreno 2016].

So it was a big challenge for us to take part in other jurisdiction with mediators experienced and trained in criminal matters. So first of all we have had to train and educate mediators in family matters and we decided to do it with our mediators themselves. Some of them had a vast experience in family mediation out of courts and all of them knew the problems of mediation in courts so we trained with real cases out of courts, and we wonder what would have happened in case these cases had been taken into courts. I would like to highlight too, that the cooperation between 
Family Mediation Services of the Basque Government (out of courts) and Mediation Services at courts has been another key for this experience to be successful.

\section{Description}

In out of court family mediation programs, it's compulsory to be registered in a list as a member of a professional body to work as a family mediator in the Basque Government Family Mediation public services. This registration requires a University degree and a 200-hour training on conflict resolution skills, family law, legal framework, evolutive psychology and family mediation processes. So the training required is focused on dealing with family conflicts in order to minimize the impact in the kids and to prevent a judicialization of family problems.

Regarding family mediation at courts, first of all we are affected by the same legal requirements to be family mediator, no matter it is at courts or out of them. The difference is that the cases referred by Judges are in high conflict when they come to us. 2017 data show this:

TABLE 1

\begin{tabular}{|l|l|}
\hline \multicolumn{2}{|c|}{$\begin{array}{c}\text { Referrals } \\
669\end{array}$} \\
\hline $\begin{array}{l}\text { Mediation process not possible } \\
378(58.79 \%)\end{array}$ \\
\hline \multirow{2}{*}{\begin{tabular}{l} 
Mediation process done \\
\multirow{2}{*}{$265(41.21 \%)$}
\end{tabular}} & Agreements \\
& 131 (49.43\%) \\
\cline { 2 - 2 } & No agreement \\
& $134(50.57 \%)$ \\
\hline
\end{tabular}

Table 1. Family mediation cases at courts, 2017.

(Source: Servicio de Mediación I ntrajudicial 2017).

The out of court service's data in 2017 are the following ones:

TABLE 2

\begin{tabular}{|l|l|}
\hline \multicolumn{1}{|c|}{$\begin{array}{c}\text { 2,064 cases } \\
\text { Pre-mediation (first stages of mediation): } 634 \\
\text { Complete mediation processes: } 854 \\
\text { Follow-up processes: } 576\end{array}$} \\
\hline \multirow{3}{*}{$\begin{array}{l}\text { Mediation process finished } \\
854 \text { cases }\end{array}$} & $\begin{array}{l}\text { Agreements } \\
(77 \%) 658\end{array}$ \\
\cline { 2 - 3 } & No agreement \\
& $(23 \%) 196$ \\
\hline
\end{tabular}

Table 2. Out of court mediation processes, 2017.

(Source: Servicio de Mediación Familiar 2017).

Follow-up of the mediation processes finished with an agreement after a year from the date of having signed the agreement ( 576 agreements in 2016, follow-up 2017):

Responsabilization: $93.6 \%$

Not responsabilization: $6.4 \%$ 


\section{Strengths}

We consider the ADR offers a range of processes. The alternative processes in family contexts are mediation, Family Group Conferences, Restorative circles, even individual assessment focused on conflict management. This variety of processes implies that the answer to the family conflict could be more accurate to every family, context and conflict. So flexibility and adaptation are two of the main advantages of this approach (Merino 2013).

When we analyse the teams we see all of them (in court programs and out of court programs) are interdisciplinary. So the intervention of these interdisciplinary teams gets a holistic approach of the conflict.

The principle of confidentiality lets the mediators know further information than in a judicial (or legal) process. People feel more comfortable in a mediation process than in court to talk about their family issues with a professional.

Nowadays, one strength is the quality and face to face work of our professional teams as all of them are interdisciplinary. It means they are able to offer a holistic approach to the conflict and design the accurate process for every situation, not only mediation but also other range of processes to manage conflicts (for instance Family Group Conferences). We also consider a strength being able to develop each process with flexibility and an open-minded attitude (Alzate and Merino 2011). The participation in these processes is always voluntary to begin and to quit, which makes them more attractive even if it's inside a judicial process.

From the Justice Department we consider that the consortium private/public of the public services of mediation has been successful and valuable. The Public services are carried out by NGOs well connected with our society and community which allows working hand in hand with the civil society and the net of public and communitarian resources. Under our experience, it would have been really hard to do this with civil servants, as we are pioneers, we need specialized mediators with the supervision of the technical Responsible officers and being backed by the political representatives at courts (formal system).

\section{Risks}

At the same time, there are some risks that concern us. For instance, the time and rhythm for the judicial procedure differs from the mediation process. This means that sometimes it is difficult to develop mediation and respect the deadline proposed by the judge. In this sense, the protocols of mediation in our country have a great impact in the flexibility of the mediation.

We first need to agree criteria for referrals with the family courts not to be overloaded as they have to do the first screening process (not every case is suitable for mediation).

We need much more individual sessions and longer processes than in criminal cases so it is really important to be efficient to be able to get back to the judicial process in a reasonable time (timing is essential).

As the mediation services are carried out by NGOs, the Basque Government need to coordinate criteria, back and promote the services with the legal operators, and control the quality of the public service (external assessments considering quality criteria, control of the data, control of the trainings provided by the NGOs responsible for the mediation services - trainings based on the knowledge of carrying out the services must be overviewed and controlled by the public administration-), the representation of the Public Service must be always public to promote them as public services and to succeed being well considered by the community. 


\section{Conclusions}

So we could conclude that one of the strengths of the mediation in the Basque Country is the training of their mediators. They are not lay advisers. Most of the mediators are well-prepared in fields as representative as family law, psychology and restorative justice practices.

As we have already commented, mediation process is held in a face to face meeting, so this direct dialogue let mediators deal with the conflict and take into account the personality traits of the parties of the conflict. So the risks of our way of developing these ADR program are minimum in comparison with ODR experiences.

Regarding family mediation at courts, I would only appoint that it is essential to be backed by the authorities (J ustice Ministry) and coordinated and supervised by public officers (civil servants) to try to extend family mediation at courts as a complementary system to the formal one and not opposed to it. This complementary system gives quality to the formal judicial system because it attends in a more human approach the parties of the conflict. The parties after theses mediation processes usually say that it is the first time at courts, that they have been heard in a close, active way which consider their feelings and needs.

\section{References}

Alzate, R., and Merino, C., 2011. Principios éticos y Código de conducta para personas y entidades mediadoras. Doxa. Cuadernos de Filosofía del Derecho [en línea], no 33. Disponible en: http://dx.doi.org/10.14198/DOXA2010.33.34 [Con acceso el 8 de noviembre de 2018].

Merino, C., 2010. Gestión de conflictos familiares desde un Servicio Público de Mediación Familiar 1996-2009. En: L. García Villaluenga et al., eds., Mediación, Arbitraje y resolución extrajudicial de Conflictos en el siglo XXI. Madrid: Reus, 169-192.

Merino, C., 2013. La mediación en situaciones asimétricas: procesos de gestión de conflictos con episodios de violencia, drogodependencias, enfermedad mental y desequilibrio de poder. Madrid: Reus, Colección de Mediación y Resolución de Conflictos.

Moreno, R., 2016. El European Forum for Restorative Justice (EFRJ): una experiencia europea para promover la justicia restaurativa y la mediación en europa y mejorar servicios públicos en el ámbito de la administración de justicia en Euskadi. Revista Aranzadi Unión Europea, 10, octubre.

Servicio de Mediación Familiar, 2017. Memoria anual 2017 [en línea]. VitoriaGasteiz: Departamento de Empleo y Políticas Sociales, Gobierno Vasco. Disponible en: http://www.euskadi.eus/contenidos/informacion/mediacion_familiar_f/es_med fami/adjuntos/MEMORIA\% 202017\%20GV.pdf [Con acceso el 8 de noviembre de 2018].

Servicio de Mediación Intrajudicial, 2017. Servicio de mediación intrajudicial (SMI) (Mediación familiar). Memoria 2017 [en línea]. Vitoria-Gasteiz: Viceconsejería de Justicia, Departamento de Gobernanza Pública y Autogobierno, Gobierno Vasco. Disponible en:

https://www.justizia.eus/servlet/Satellite?blobcol=urldata\&blobheader=applic ation \% 2Fpdf\&blobheadername1 =Content-

Disposition\&blobheadervalue1=filename\%3DSMI_familia_2017_\%283\%29.pdf \&blobkey $=i d \& b l o b t a b l e=$ MungoBlobs\&blobwhere $=1290510816104 \&$ ssbinary $=\mathrm{t}$ rue [Con acceso el 8 de noviembre de 2018]. 